\title{
Assédio moral no trabalho: dilacerando oportunidades
}

\author{
Workplace harassment: tearing opportunities to pieces
}

Valdir Machado Valadão Júnior ${ }^{1}$

Juliana Moro Bueno Mendonça ${ }^{2}$

\begin{abstract}
Resumo
O assédio moral é um tema recorrente na literatura de negócios, com perspectivas, embora distintas, convergentes em um aspecto: essa prática deve ser banida das organizações, e, para isso, é necessário compreendê-la em maior profundidade. Nesse sentido, este estudo analisa processos de assédio moral com o objetivo de identificar as divergências e convergências entre as sentenças/processos procedentes verificados na Justiça do Trabalho, bem como analisa os discursos dos autos, das vítimas e dos gestores das organizações responsabilizadas, adotando como referência algumas das categorias de assédio moral. Diferentemente das pesquisas tradicionais, que consideram a perspectiva das vítimas, esta pesquisa vai além ao considerar, também, os gestores das organizações onde ocorreram os casos analisados. A estratégia de pesquisa utilizada é o estudo de caso, a partir da triangulação de dados obtidos com entrevistas com as vítimas e os gestores e análise de documentos. Com esse delineamento, o estudo foi dirigido em duas fases complementares: na primeira realizou-se o mapeamento das ocorrências de assédio moral na Justiça do Trabalho e na segunda analisaram-se dez casos de assédio moral contra mulheres que trabalharam em empresas privadas de grande porte. Os resultados mostram divergências expressivas nas categorias entre a ótica das vítimas e dos gestores Além disso, eles revelam, não apenas nos discursos dos entrevistados, uma miopia em relação às múltiplas causas de assédio moral no mundo do trabalho, mas, também, nos elementos dos processos jurídicos. Com ênfase nos gestores, as contradições e equívocos sobre o tema preocupam, e os álibis naturalizados, em suas expressões e falas, tentam levar a problemática para a margem, utilizando o tom de "brincadeira" e eufemismos.
\end{abstract}

Palavras-chave: Negócios. Organizações. Assédio moral. Justiça do Trabalho.

\begin{abstract}
Harassment is a recurrent theme in business literature, with perspectives, although different, converging on one aspect: this practice should be banned from organizations, and, to do this, there is a need to understand it in greater depth. Thus, this study analyzes harassment lawsuits in order to identify divergences and convergences between the sentences/lawsuits pursued by the Labor Justice, and it also analyzes discourses in the court records, as well as discourses by the victims and managers from organizations held accountable, adopting as reference some harassment categories. Unlike traditional scientific studies, which take into account the victims' perspective, this study goes beyond by also considering managers from organizations where the cases under analysis took place. The research strategy used is case study, by means of triangulation of data obtained through interviews with victims and managers and documentary analysis. With this design, the study was conducted in two complementary phases: the first mapped cases of harassment filed with Labor Justice and the second analyzed ten cases of harassment against women who have
\end{abstract}

Artigo submetido em 10 de junho de 2013 e aceito para publicação em 18 de setembro de 2014.

\section{DOI: http://dx.doi.org/10.1590/1679-39519022}

1 Doutor em Engenharia da Produção pela Universidade Federal de Santa Catarina; Professor associado da Universidade Federal de Uberlândia. Endereço: Av. João Naves de Ávila, 2121 - Campus Santa Mônica - Bloco F - $2^{\circ}$ andar, Santa Mônica, CEP 38408-100, Uberlândia - MG, Brasil. E-mail: valdirir@ufu.br

2 Doutoranda em Administração pela Universidade de Brasília - UNB; Professora substituta da Universidade Federal de Uberlândia. Endereço: Av. João Naves de Ávila, 2121 - Campus Santa Mônica - Bloco F - 2º andar, Santa Mônica, CEP 38408-100, Uberlândia MG, Brasil. E-mail: juliana mbueno@hotmail.com 
worked in large private companies. The results show significant differences in the categories between the victims and managers' perspectives. Moreover, they reveal, not only in respondents' discourses, myopia regarding the multiple causes of harassment in the labor world, but also in the elements of legal proceedings. With an emphasis on managers, the contradictions and mistakes on the theme are a matter of concern and naturalized alibis, in their expressions and speeches, try to bring the issue to the borderland, by using the tone of "joke" and euphemisms.

Keywords: Business. Organizations. Harassment. Labor Justice.

\section{Introdução}

No Brasil, o invólucro do trabalho foi construído sob a égide de um regime de subordinação colonial, com mão de obra local, formada por índios e negros, tidos como raça inferior. E as práticas direcionadas a essa "raça inferior", como, domar, humilhar e rebaixar, oferecem-nos "lembranças" das ações de exploração no trabalho (BARRETO, 2006).

Visto desse modo, os álibis moldados em defesa da honrosa violência, que transportam o agressor a uma dimensão de sucesso, são composições racionalizadas, ou seja, consagradas e com raízes na Antiguidade, dotadas apenas de sutis variações (GAY, 1995).

Portanto, na chamada Era do Conhecimento do Século XXI, que deveria libertar, a labuta rotineira parece estar em constante guerra, como Freitas (2007b, p. 284) observa: "[...] guerra contra o tempo, guerra dos mercados, guerra dos talentos, guerra pelos consumidores, guerra pela sobrevivência, guerra dos empregos". Esse pensamento evidencia a incidência de assédio moral e aprisiona uma sociedade acentuadamente narcísica, pois os meios costumam justificar os fins, sugerindo explicações que banalizam a relevância dessa doença social em que consiste o assédio moral (HELOANI, 2004; FREITAS, 2007a).

Na prática, a investigação dos comportamentos abusivos dentro das organizações não é tarefa fácil, já que poucos querem falar sobre o assunto, e a quantidade de pessoas que querem ouvir parece ser ainda menor. Nessa direção, há décadas, pesquisadores ao redor do mundo estão trabalhando com sindicatos, organizações de saúde e outros organismos profissionais para obterem acesso aos casos de assédio, a fim de promover um avanço nas discussões acerca do tema (RAYNER, SHEEHAN e BARKER, 1999). Ademais, vale ressaltar a importância de abarcar outras óticas, e não apenas das vítimas, quando a discussão é assédio moral no trabalho. Salin (2003b) e Daniel (2009) indicam que é preciso trabalhar nessa direção, visto ser raro encontrar, por exemplo, estudos que compreendam olhares de gestores(as) e, principalmente, de agressores(as).

Diante do exposto, é fundamental mapear as ocorrências de assédio moral, ainda mais aquelas consideradas graves, por não serem tratadas de maneira adequada pelas organizações, já que essas se desenrolaram até o último recurso, a saber, o âmbito jurídico. Com base nessa perspectiva, esta pesquisa é realizada em duas fases complementares e tem como objetivo geral identificar as divergências e convergências entre as sentenças/processos procedentes verificados - junto à Justiça de Trabalho (jurisdição em Uberlândia) bem como analisar os distintos discursos dos autos, das vítimas e dos (as) gerentes, em dez casos selecionados, usando como referência algumas das categorias de assédio elencadas por Bradaschia (2007).

Além desta introdução, o texto está dividido em cinco partes. Primeiro, apresentam-se algumas considerações sobre o mundo do trabalho com ênfase no conceito de intolerância institucionalizada (RICCEUR, 2000; LE GOFF, 2000) e civilização de dopping (ENRIQUEZ, 1997). Em seguida, mostra estudos interdisciplinares nas categorias de assédio moral, ressaltando as principais lacunas de investigação sobre o tema. Na terceira parte, o delineamento da etapa empírica da pesquisa é exposto, abarcando as duas fases que compõem o estudo. Na quarta parte, são apresentados os resultados de nossa análise, para, finalmente, tecer as considerações finais, na quinta parte. 


\section{O Mundo do Trabalho}

A lógica da intolerância do Outro nas sociedades está a serviço de interesses daqueles que se julgam ameaçados e mostra justificativas permeadas nos elementos da cultura que validam a expropriação do status humano do Outro (HÉRITIER, 2000). Esse flagelo cunha-se no raciocínio reducionista, do qual ninguém está isento.

Ricceur (2000, p. 20) explica que "[...] dois componentes são necessários à intolerância: a desaprovação do outro e o poder de impedir que esse outro leve sua vida como bem entenda". Desse modo, sem considerar o conceito de intolerância institucionalizada, "[...] é impossível explicar as fogueiras, os patíbulos, as decapitações, as guilhotinas, os fuzilamentos, os extermínios, os campos de concentração, e os fornos crematórios". Nesse sentido, Mereu (2000, p. 42-43) observa que a intolerância "entra na instituição por meio de uma determinação legal que é justificada por duas projeções ideológicas diferentes: a violência justa e a violência injusta". A primeira é dignificada e "[...] é empregada por todos aqueles que estão à frente de uma instituição dominante [...]", ou seja, qualquer oposição caracterizar-se-á pelo segundo tipo de violência, a injusta e monstruosa, que é "[...] empregada pelos heréticos contra a instituição ou contra seus fiéis" (MEREU, 2000, p. 43).

A justificativa do capital ancora-se na necessidade de domesticação dos indivíduos, a fim de evitar a "marginalidade" no seio social (BARRETO, 2006). Sob esse ângulo, é importante considerar que os álibis para a agressão "[...] são fenômenos culturais coletivos; florescem ou fenecem no domínio público" (GAY, 1995, p. 123). Nesse cenário, a dominação do capital sobre o trabalho especializa-se e acontece na esfera afetiva, subjetiva e psicológica (HELOANI, 2010).

Os indivíduos, nesse ambiente, estão sempre em estado de atenção, o que lhes provoca uma série de disfunções fisiológicas, embora ainda lhes garanta bom desempenho. No entanto, "[...] quando esses indivíduos não são mais úteis, eles são descartados apesar de todos os esforços despendidos" (ENRIQUEZ, 1997, p. 6).

Sobre as inovações oriundas da terceira Revolução Industrial ou Revolução Técnico-científica, é necessário expor que essas passaram a exigir "[...] uma organização do trabalho pautada em características de flexibilidade, aprendizagem contínua, custos sempre em queda, desempenhos sempre mais elevados, equipes multiculturais e mobilidade em todos os sentidos" (FREITAS, HELOANI e BARRETO, 2008, p. 8). E é nesse contexto que as formas de dominação baseadas na gestão pelo inconsciente surgem (HELOANI, 2010). E os discursos da área de Gestão de Pessoas parecem ser uma nova roupagem para a velha prática de controlar as pessoas, controle esse que está cada vez mais disfarçado, pois, em vez da repressão, utiliza-se a sedução.

Observa-se que, no universo do trabalho, tanto o poder real quanto o simbólico reinam, sendo este último alimentado pelas ciladas, pela insídia e pela traição a partir de conluios, de conspirações e métodos astutos. Faria (2007, p. 81) explica que as tramas organizacionais são cultivadas como "[...] arte suprema, pois nesta concepção a hipocrisia bem praticada é sinal de esperteza e o jogo de cena nos bastidores e no público é demonstração de habilidade política ou competência gerencial".

Posto dessa maneira, se o reposicionamento do trabalho como categoria central na vida moderna gerou limites, como a intolerância e as desigualdades, quando a questão volta-se para a ideia de gênero, esses limites se acentuam (SIQUEIRA, 2008; MATTOS, 2009).

Nesse sentido, compreender questões interiores que norteiam as práticas torna-se fundamental, visto que, para Davel e Vergara (2001, p. 42), considerar a subjetividade nos estudos organizacionais é buscar compreender "a experiência humana em sua fonte mais complexa, rica e profunda". A subjetividade é expressa em "pensamentos, condutas, emoções e ações", e sua dinâmica permite "desvendar a pluralidade e 
heterogeneidade de linguagens, espaços e práticas que nos governam diariamente" (DAVEL e VERGARA, 2001, p. 43).

Ademais, não se pode permitir o livre curso da intolerância, sendo vital intervir e não deixar, por medo, as partes entregues a si mesmas, pois "a tolerância é uma construção, uma conquista" (LE GOFF, 2000, p. 38).

Face ao exposto, torna-se necessário ancorar o tema assédio moral no trabalho aos debates teóricos e às investigações empíricas, o que é evidenciado na próxima seção, com o propósito de contribuir para o avanço do conhecimento multidisciplinar que envolve a discussão.

\section{Assédio Moral no Trabalho}

\section{Discussões conceituais}

O assédio moral (AM) é um fenômeno antigo, conhecido e presente em diversas culturas, entretanto, passou a ser estudado, sistematicamente, somente a partir dos anos 1980 (LEYMANN, 1996a). No Brasil, os debates a respeito do tema acaloram-se duas décadas a posteriori das pesquisas internacionais (FREITAS, 2007a), as quais são mais afluentes na Escandinávia. Freitas (2001, p. 9) afirma que o "[...] fenômeno em si não é novo, contudo, a sua discussão e a sua denúncia, em particular no mundo organizacional, constituem, sim, uma novidade" (grifo nosso).

O processo do assédio envolve um desequilíbrio de poder percebido entre vítima/autor, desencadeando um ambiente hostil de trabalho (ADAMS, 1992; SALIN, 2003b). Para Salin (2003b), essa tipologia de violência ocorre devido aos atos negativos repetidos em direção a um ou mais indivíduos. Todavia, a autora argumenta que tal definição não abarca a questão da intenção, estando essa atrelada à percepção subjetiva da vítima. Já as exposições de Piñuel y Zabala e Cantero (2002), e Freitas, Heloani e Barreto (2008) compreendem a intencionalidade do agressor.

Vale ressaltar que Adams (1992) amplia os tipos de fontes do AM, pois a autora engloba tanto as fontes internas, citadas também por Einarsen (2000), como as fontes externas, que são compostas por clientes, fornecedores ou a população em geral. Ademais, Adams (1992) enfatiza que a discussão dessa violência, para muitas organizações, consiste em um tabu.

Apesar da diversidade de termos utilizados ao redor do mundo para nomear o AM, como mobbing, bullying, harassment e pychological terror, bem como a variedade de definições, é importante destacar que a definição de Leymann exprime um elemento em consenso, que diz respeito ao entendimento de AM como um processo, e não como um fenômeno pontual: "Em outras palavras, a distinção entre 'conflito' e 'mobbing' não está focada no que ocorreu ou como isso aconteceu, mas sim na frequência e na duração do que aconteceu ou está acontecendo" (LEYMANN, 1996a, p. 168, grifo nosso).

A partir das considerações realizadas, é possível pensar nos elementos centrais que compõem o AM no trabalho, aglutinados e destacados na conceituação a seguir: o assédio moral caracteriza-se por atos negativos (diretos ou indiretos) empreendidos por um ou mais indivíduos, de maneira sistemática e de longo prazo, a uma ou mais vítimas, envolvendo um desequilíbrio percebido de poder (não apenas no sentido formal), resultando em graves danos psicológicos (e, às vezes, até físicos) para a(s) vítima(s).

A prevalência dos estudos sobre o tema não ocorre na Administração, mas, sim, na Psicologia (BRADASCHIA, 2007). Todavia, como as organizações são palco do assédio, é válida uma maior atenção dos pesquisadores da área sobre o tema, pois, apesar do assédio moral ainda não ser formalmente crime no Brasil, é uma epidemia silenciosa (PIÑUEL y ZABALA, 2003) que mina as possibilidades em diversos flancos, quais sejam: individual, grupal e social. $\mathrm{O}$ fato é que existe uma tortura psicológica incisiva sobre as 
vítimas, e, para as testemunhas/espectadores, a contaminação ocorre tal qual acontece com fumantes passivos.

Cabe ainda mencionar algumas brechas que revelam carências de pesquisa, quais sejam: antecedentes subjacentes à ocorrência do tema, o comportamento de colegas e supervisores em uma situação de assédio, e as ações de gestores frente à problemática. De modo geral, é necessário ampliar o olhar dos estudos tradicionais focados apenas na versão da vítima, assim, congregar outras óticas torna-se fundamental para a compreensão do assédio moral no trabalho (EINARSEN, 2000; SALIN, 2003b).

\section{Categorias de análise}

Na sequência, será apresentado um grupo de categorias que, a partir da literatura, possibilita compreender como se constitui esse processo complexo que é o AM:

- Causas de Assédio Moral: no intuito de especificar distintos comportamentos agressivos, Einarsen (1999) os nomina em três tipos, conhecidos como dispute-related, predatory-bullying e um mix entre o primeiro e o segundo. Baillien, Neyens, Witte et al. (2009) buscaram integrar as linhas de pesquisas sobre antecedentes do bullying, construindo um modelo de três caminhos que podem evoluir para o AM no trabalho. Leymann (1996a), ao invés de enfatizar estudos sobre personalidade, focaliza suas discussões nas questões ligadas ao ambiente de trabalho, e, para isso, aponta a performance gerencial deficiente como causa precursora do AM, distinguindo potenciais diferenças no comportamento gerencial entre os gêneros. O autor chama a atenção, também, para as precárias condições organizacionais que dão espaço à instalação da violência. Já Corrêa e Carrieri (2007) afirmam que as relações de poder, reais ou percebidas, representam o pano de fundo dos casos de assédio, estando presentes nas estruturas formais e informais.

Em uma visão mais ampla, Piñuel y Zabala e Cantero (2002) identificaram os motivos causadores das agressões no ambiente de trabalho, os quais são apresentados a seguir: o ciúme profissional e a inveja em relação às competências do outro; a imaginação do agressor de que a vítima representa uma ameaça profissional; e, em terceiro lugar, as causas são relacionadas às diferenças (cultura, educação, orientação sexual etc.). Além dos fatores individuais, fatores organizacionais que favorecem o AM foram mencionados por Piñuel y Zabala e Cantero (2002), como, por exemplo, um ambiente de trabalho que estimula a competição exacerbada, sendo também os estilos autoritários de liderança citados em outras pesquisas (EINARSEN, 1999; SALIN, 2003a; AYOKO e CALLAN, 2010). Salin (2003a) estrutura a prática do assédio como resultado da interação entre três grupos, ou, pelo menos, dois deles. As causas do AM, portanto, não podem ser atribuídas de forma unidirecional, sendo necessário abranger diversas óticas, de maneira sistêmica, bem como considerar três níveis de análise inter-relacionados, a saber: individual, organizacional e social (LEYMANN, 1996a; FREITAS, 2007a; BRADASCHIA, 2007). Isso, porque culpar a vítima, ou apenas o agressor como se esse fosse uma "maçã podre", acaba por simplesmente banalizar o assunto (DUFFY, 2009, p. 246).

- Consequências de AM: a patologia desse mal traz impactos negativos, também, para as organizações, tendo em vista o descompromisso com o trabalho em razão do sofrimento causado pela violência que encurrala a vítima, de tal maneira que esta passa a duvidar de suas capacidades profissionais. Ainda, a vítima é submetida a um exílio interior que acaba por afetar, negativamente, diversas áreas de sua vida, inclusive, suas perspectivas de carreira (HIRIGOYEN, 2010).

Custos do AM: o consenso relacionado a este tópico diz respeito ao efeito cascata dos custos do $\mathrm{AM}$, visto que as pessoas exercem na sociedade múltiplos papéis (MARTININGO FILHO e SIQUEIRA, 2008). Os custos individuais refletem-se na organização no que se refere à redução da satisfação das vítimas com o trabalho, o que, por sua vez, pode reduzir o comprometimento do 
funcionário com a empresa (KEASHLY e NEUMAN, 2004). Outro prejuízo para a empresa oriundo do assédio é a potencial perda de profissionais capacitados, pois as vítimas trocam de emprego mais frequentemente do que aquelas que não são vítimas (BERTHELSEN, SKOGSTAD, LAU et al., 2011). Em situações de convívio com chefes tiranos, a ansiedade predominante no local de trabalho pode originar níveis substanciais de medo entre os potenciais alvos do agressor, com graves impactos para a eficiência e a eficácia do trabalho do grupo. Desse modo, o clima "tóxico" faz emanar emoções negativas entre os funcionários, e o medo, a desconfiança e a raiva passam a reinar (KEASHLY e NEUMAN, 2004). Assim, os reflexos dos custos individuais e organizacionais recaem sobre a sociedade, podendo citar, a título de exemplos de ônus: maiores custos relativos a aposentadorias precoces, custos relacionados à perda da produtividade e custos relacionados aos tratamentos médicos (FREITAS, 2007a).

- Perfil da Vítima: Em decorrência de distintas escolhas metodológicas, não é possível afirmar, por exemplo, de maneira geral, qual é o sexo mais agredido, haja vista que nem todas as vítimas expõem suas vivências. Hirigoyen (2010) questiona os diferentes resultados estatísticos nas pesquisas sobre AM, incorporando, em sua exposição, a análise do contexto sociocultural. Na visão dessa pesquisadora, as mulheres são as vítimas mais frequentes e sofrem um tipo de assédio diferente, porque conotações machistas ou sexistas estão, frequentemente, presentes nos discursos dos agressores.

A respeito da idade das vítimas, o levantamento realizado por Hirigoyen (2010) não mostrou incidência em indivíduos com idade inferior a 25 anos, sendo alvos mais frequentes trabalhadores acima de 50 anos, que costumam ser julgados menos produtivos e não suficientemente adaptáveis. Contudo, outros estudos (FREITAS, 2001; BORSOI, RIGOTTO e MACIEL, 2009; PIÑUEL y ZABALA; CANTERO, 2002) expõem que profissionais mais jovens e com menor experiência, como trainees, também são alvos dessa modalidade de violência.

- Direções de AM: as tipologias do AM ocorrem, comumente, em quatro direções: AM ascendente, descendente, horizontal ou misto (LEYMANN, 1996; HIRIGOYEN, 2010; FREITAS, 2001). No entanto, o de menor ocorrência, de acordo com Bradaschia (2007), é o assédio ascendente. Vale observar que os distintos contextos podem alterar as direções mais registradas. Hirogoyen (2010) expõe, em seus resultados, o assédio misto como o segundo mais vigente. Já Piñuel y Zabala e Cantero (2002) distinguem as direções do assédio em duas óticas: da vítima e da testemunha.

- Perfil do Agressor: Bradaschia (2007, p. 124) afirma que "[...] são raros os estudos que tratam do perfil do agressor", sendo necessário, portanto, incluir outras óticas. Como o assédio descendente tem maior ocorrência, é importante entender o que diferencia um agressor de um "chefe rígido" não agressor. Existe uma tendência de que os primeiros sejam injustos, inconsistentes e interessados mais em si mesmos do que legitimamente na organização. Ainda, são explosivos emocionalmente e abusam do poder e da autoridade que possuem. Já os "chefes rígidos" agem de forma justa e coerente, de maneira controlada, focalizando os resultados organizacionais (DANIEL, 2009).

Com ênfase na percepção das vítimas, Tracy, Lutgen-Sandvik e Alberts (2006) analisam metáforas empregadas por vítimas de situações de AM no trabalho. E, na busca por preencher a lacuna de pesquisas sobre o agressor no processo do AM no trabalho, Jenkins, Zapf, Winefield et al. (2011) entrevistaram vinte e quatro gerentes acusados de exercer terror psicológico, como parte de um estudo exploratório. Os resultados mostram quatro principais temas identificados na análise das entrevistas: (1) ambiente de trabalho estressante, caracterizado como um antecedente para o AM; (2) as diferentes práticas rotuladas como "AM" não são legítimas, como, por exemplo, as impopulares decisões de gestão; (3) o agressor acusado é, na verdade, o alvo - o comportamento inadequado dos reclamantes e o limite se configura como turvo entre as alegações do agressor e da vítima-; e (4) as consequências de ser acusado de AM podem ser desastrosas, como, por exemplo, o impacto psicológico e físico da alegação. Os autores apontam que o estudo confirma os antecedentes do AM discutidos em outros trabalhos (SALIN, 2003a; PIÑUEL y ZABALA e CANTERO, 
2002; BRADASCHIA, 2007), sendo esses baseados na combinação entre a cultura organizacional, o ambiente social do trabalho e os comportamentos (personalidade), tanto dos agressores quanto das vítimas (JENKINS, ZAPF, WINEFIELD et al., 2011).

- AM como Processo (incidência, duração, fases, táticas, a lei do silêncio, e reação das vítimas): a incidência do problema mostra-se divergente quando comparada a estudos de distintos países (AGERVOLD, 2007), devido às particularidades culturais, bem como às diferentes escolhas metodológicas de cada um; contudo, a duração dessa violência guarda, em si, similaridades. O consenso está posto sobre a longevidade do sofrimento, ou seja, não há caracterização de AM em agressões pontuais. A respeito da duração desse mal, Bradaschia (2007) encontrou variações significativas nas pesquisas realizadas; todavia, a maioria das investigações registra que o assédio prolonga-se por mais de um ano. Mas, apenas conhecer a duração da violência moral, que é um dado numérico, em si mesmo, não traz riquezas de informações. Assim, torna-se fundamental conhecer o desenvolvimento do caso, visto que há uma progressão ao longo de sua ocorrência. O AM, portanto, ocorre em fases, as quais, de maneira sequenciada, agravam-se. A primeira fase refere-se a ataques e/ou mesquinharias que não caracterizam propriamente o assédio, no entanto, com a continuação dos atos negativos, esses passam a um segundo estágio, chamado de AM propriamente dito. A terceira fase representa a intervenção da gestão de pessoal da organização e, caso isso não ocorra de maneira eficaz, o processo poderá se desenrolar até a quarta fase, entendida pela exclusão do indivíduo do mercado de trabalho (LEYMANN, 1996b).

É importante frisar que as vítimas têm sérias dificuldades para discernirem a instalação do AM em suas vidas, e a não compreensão sobre a dimensão do problema que estão sofrendo transforma-se em um verdadeiro drama. Além disso, as barreiras de identificação precoce do assédio podem levar a dificuldades práticas futuras para a obtenção de apoio institucional (LEWIS, 2006). O assédio é como uma ferida interna e, por isso, não se vê nenhum arranhão. Não ocorre, pois, de modo alarmante, fazendo barulho, mostrando sinais claros. Diante desse quadro, a profilaxia deve ser contínua.

Bradaschia (2007) explica que as várias táticas utilizadas podem mudar de país para país, indicando até mesmo relação com a cultura da região. Vale ainda destacar que as táticas podem apresentar particularidades em cada direção. No assédio horizontal, por exemplo, é possível elencar: recusa do ato de ensinar e, quando o faz, é de forma complicada e pejorativa, induzindo ao erro, divulgação de rumores, distorção dos fatos e sabotagem (CORRÊA e CARRIERI, 2007).

A perversidade do agressor surge, de maneira mais refinada, a partir da escolha de algumas táticas sutis que levam a vítima, às vezes, a duvidar se, de fato, entendeu bem a situação. A vítima fica se questionando se está exagerando ou não (FREITAS, 2001; HIRIGOYEN, 2010). Além das táticas de AM, conhecer como as vítimas respondem a esse assédio pode contribuir para a identificação dos elementos que facilitam ou dificultam a vítima a comunicar tal problemática. Piñuel y Zabala e Cantero (2002) destacam que 46\% das vítimas se mostram passivas em relação à violência sofrida, silenciando-se sobre o problema e deixando o tempo passar. Xavier, Barcelos, Lopes et al. (2008) registraram que 38,49\% das vítimas relataram o ocorrido dentro da organização para um superior, todavia apenas $20 \%$ afirmaram que alguma providência foi tomada. Dessas, $51 \%$ informaram insatisfação quanto à maneira pela qual o problema foi tratado, e apenas $8,6 \%$ mostraram-se satisfeitas. É válido ressaltar a justificativa de algumas vítimas que não reagiram por não acreditarem na ação providencial da organização.

Rodrigues (2009) entende que as vítimas sentem que têm o dever de tolerar o assédio. Essa reação talvez seja dada pela necessidade de manutenção no emprego. Nesse sentido, as questões de cunho econômico e político de uma sociedade também contribuem para a aceitação do problema. Nota-se a dificuldade de a vítima romper a mordaça do AM, haja vista ser esse um processo velado e degradante, em que a lei imperativa, subjacente ao assédio, é a do silêncio. Diante disso, consideramos neste estudo o subitem a lei do silêncio apresentado por Bradaschia (2007), como elemento integrante do próprio conceito de AM. 


\section{Aspectos Metodológicos}

\section{Caracterização e delineamento da pesquisa}

Esta é uma pesquisa descritiva e de abordagem qualitativa (ANDRADE, 2004; MARCONI e LAKATOS, 2006). As estratégias de pesquisa escolhidas baseiam-se na análise de arquivos e no estudo de caso (YIN, 2001). Ambas as escolhas partem de pesquisas realizadas junto à Justiça do Trabalho, jurisdição de Uberlândia/MG, no que diz respeito aos registros sobre o tema, entre os anos de 2007 a 2011. Esses registros foram obtidos, consultando-se as pastas eletrônicas dos juízes, com a utilização da palavra-chave, assédio moral, nas cinco Varas do Trabalho, em virtude da impossibilidade de se realizarem buscas textuais via site. Apenas os processos que foram tramitados em segredo de justiça não foram acessados. Em meados de março de 2012, foi possível reunir as sentenças encontradas, as quais totalizam 243. Com a obtenção dessa documentação, o estudo se desdobrou em duas fases sequenciais, que serão detalhadas nas subseções a seguir.

\section{Identificação do panorama regional - primeira fase}

A leitura e a sistematização das informações das sentenças foram realizadas no mês de junho de 2012. Para tanto, foi necessário, também, por intermédio do número de cada processo, verificar as decisões em outras instâncias, via site do Tribunal Regional do Trabalho - TRT (terceira região/MG). O estudo, na sequência, consistiu na separação das sentenças em dois blocos: casos procedentes e casos improcedentes. Filtraram-se como procedentes os casos em que a vítima foi indenizada por danos morais decorrentes de AM. Dentre esses casos, ainda foi verificado se o ocorrido com a vítima, de fato, alinhava-se ao conceito de AM discutido neste estudo.

As sentenças procedentes foram analisadas em seus conteúdos, no intuito de identificar as divergências e convergências entre elas. As sentenças improcedentes também foram averiguadas, no sentido de elencar as razões pelas quais o AM não foi configurado. Para enriquecer o conjunto de informações nessa fase da pesquisa, foi preciso verificar os processos procedentes fisicamente nas Varas do Trabalho. Tal ação também foi fundamental para a elaboração do banco de dados com informações sobre as vítimas, a fim de contatá-las na etapa seguinte. Isso porque, como eram poucos os casos em que constava um telefone da vítima, constando apenas o endereço - antigo em algumas situações, anotou-se o contato dos advogados para procura posterior.

\section{Processo de escolha para aprofundar o estudo - segunda fase}

Esta fase consiste na triangulação de dados, agregando evidências aos arquivos analisados. As fontes primárias são baseadas em: a) entrevistas narrativas com as vítimas; b) entrevistas semiestruturadas com os gestores das organizações responsabilizadas por AM; e c) observações diretas com anotações no diário de campo (YIN, 2001). Como fonte secundária, têm-se os processos jurídicos alocados na Justiça do Trabalho. Vale lembrar que, para cada entrevistada, um termo de consentimento foi fornecido, e, além disso, conservou-se em anonimato a identidade das pessoas entrevistadas, bem como das organizações.

Dois critérios foram considerados para a seleção dos casos analisados em profundidade: mulheres que trabalharam em empresas privadas de grande porte. Contempla-se, desse modo, a discussão que afirma ser o AM dirigido, em muitas ocorrências, para grupos considerados minorias, nesse caso, não pela quantidade, mas, sim, pela construção social das diferenças entre homens e mulheres que acabam erguendo barreiras de crescimento profissional na organização para essas últimas (FREITAS, 2001; MATTOS, 2009). Dentre os 49 casos procedentes, 18 deles inseriram-se no critério duplo explicado, e foi possível entrevistar (em agosto e setembro de 2012) 10 mulheres (o que resultou em 231 páginas de transcrições). A análise das entrevistadas narrativas, não estruturadas e em profundidade (JOVCHELOVITH e BAUER, 2008) baseou-se na análise de discurso (GILL, 2008), a partir da leitura sistematizada de todo o material. Para complementar as dez entrevistas, foram copiados os autos dos processos referentes às mesmas, resultando em 1.200 laudas, que 
receberam o tratamento da análise de conteúdo (BAUER, 2008). Para essa análise, uma leitura exaustiva foi realizada, como também a identificação de elementos para cada categoria, e, ainda, intercruzamentos entre as categorias, representando mapas de conhecimento.

É importante explicar que um processo contém diversas petições. Diante disso, foram selecionados, em cada reclamação trabalhista, os seguintes documentos: a petição do(a) reclamante (anexadas às provas, como por exemplo: registro de e-mails, registro de mensagens via celular, atestados de saúde, testemunhos etc.); a defesa da reclamada; e, quando disponível, o estatuto da empresa. Agregou-se também a esses documentos copiados os já encontrados por site, ou seja, as decisões em cada instância.

Fecham a triangulação dos dados as entrevistas com os responsáveis de maior nível hierárquico em cada empresa na qual ocorreram os casos analisados em profundidade. Todas as empresas responsabilizadas nos 10 casos foram consideradas (contatos e entrevistas realizadas de agosto a outubro de 2012). Dentre as possibilidades, listamos nove empresas como primeiras culpadas em juízo e quatro como segundas responsabilizadas em juízo, totalizando 13 organizações. Dessas, foi possível realizar apenas seis entrevistas (em quatro, foi autorizada a gravação - resultando em 56 laudas transcritas e analisadas via análise de discurso - uma foi realizada por e-mail e outra, sem o uso do gravador).

Cabe explicar que o intuito não foi entrevistar os agressores, até porque a maioria deles, segundo as vítimas, já não trabalhava mais na empresa em que o problema ocorreu. Entende-se que o(a) gestor(a) pode já ter sido vítima de AM, ou mesmo ser um potencial agressor. Todavia, o objetivo pautou-se em entender a maneira como a empresa, na pessoa do responsável por essa questão, compreende e realiza a mediação do assédio (na ausência de um profissional específico da área de RH na filial, buscou-se contatar o(a) gerente geral, ou seja, aquele que ocupa cargo de maior nível hierárquico na filial). Apesar desse esclarecimento, é importante indicar que, em um dos casos, o gestor entrevistado era o próprio agressor citado no processo jurídico.

Vale ainda mencionar as dificuldades em cada ótica da pesquisa. Para a obtenção dos processos jurídicos, foram necessárias várias visitas, conversas, autorizações, vários retornos e esperas. Apesar disso, sempre houve cordialidade, respeito e profissionalismo no tratamento. No caso das vítimas, a dificuldade inicial foi localizá-las. Contudo, para realizar as entrevistas, o acesso às vítimas foi mais fácil, se comparado aos gestores, apesar do trauma dessas vítimas (na maioria dos casos, a vítima desabafou, pois sentia que alguém estava discutindo um assunto tão encoberto, mas para elas muito real). Em relação às empresas, empreendeuse mais tempo, a partir de diversas tentativas de contatos, na busca de retornos que, em muitos casos, sequer aconteceram. Esse fato será explorado na análise dos resultados na subseção a respeito das entrevistas não concedidas.

\section{Análise dos Resultados}

\section{Panorama regional}

Observou-se que, dentre os 243 processos levantados, aproximadamente, $80 \%$ foram registrados como improcedentes, e apenas 49 casos, citados como procedentes. Uma das justificativas para o volume de processos improcedentes foi a dificuldade de comprovação do AM na esfera jurídica, visto que é de responsabilidade do reclamante evidenciar o ato ilícito, o nexo causal e o dano. Essa dificuldade aumenta tendo em vista a sutileza das táticas que compõem essa tipologia de violência (FREITAS, 2001; HIRIGOYEN, 2010). Por esse motivo, dos 49 casos, o testemunho de terceiros, em 42 deles, foi fundamental para a comprovação do assédio. Dessa maneira, a prova testemunhal é valiosa para a comprovação do assédio, já que nem sempre o agressor se expõe de maneira que a vítima possa coletar provas físicas (bilhetes, e-mails, mensagens por celular). Além disso, a própria vítima tem dificuldades em compreender a sua dor e nem "sonha" que registrar os golpes sofridos pode ser relevante (LEWIS, 2006). 
Devido à expressão do número de casos improcedentes (80\%), uma leitura sistematizada na base documental desta pesquisa, com o propósito de elencar as razões principais que não caracterizaram o $\mathrm{AM}$, tornou-se necessária, bem como a identificação das justificativas, na ótica do Direito, que contribuíram para a não indenização dos casos. As considerações mais comentadas dizem respeito a ações que, por si só, não caracterizam AM. São elas: o trato no relacionamento interpessoal, especialmente, entre superior e subordinado, como, por exemplo: falha na comunicação entre as partes, falta de polidez no trato interpessoal, exasperação por parte do superior hierárquico que não chegue ao ponto de deteriorar o ambiente de trabalho e incompatibilidade entre o superior hierárquico e o subordinado; as cobranças no cumprimento de metas (inerentes à própria profissão); e as condutas legítimas do empregador sem abuso do poder diretivo, como, por exemplo: suspensões justificadas, rigor ao aplicar penalidades, transferência de funcionário de setor e alteração de jornada de trabalho. É possível reconhecer que tais considerações podem não caracterizar o AM, no entanto, elas contribuem para a concretização do processo.

Já a respeito do que compromete o deferimento da petição, vale destacar as justificativas mais recorrentes dos juízes: prova testemunhal frágil - falta de precisão nos depoimentos, provas insuficientes, contradições aparentes e manifestas em relação à petição inicial, e ausência de provas robustas em relação aos fatos alegados na exordial, o que acaba por não comprovar o nexo causal, ou seja, o dano em função do ato ilícito que, por definição, deve ser reiterado para se configurar como AM.

A respeito do aumento do número de processos sobre o tema ao longo dos anos, um dos juízes menciona em um parecer que o $\mathrm{AM}$ "[...] exige prova robusta e convincente porque a pretensão de indenização por danos morais vem se tornando 'a mãe de todas as gerências"” (AUTOS, 2012). É preciso, portanto, refletir sobre a diferença entre um chefe rígido e um agressor (DANIEL, 2009), ademais, cabe ressaltar que pode ser tênue o limite entre o que é agressão e o que não se configura, tendo em vista que o processo avança e se desenrola em fases (LEYMANN, 1996b). De fato, como o juiz afirma, "meros aborrecimentos não são indenizáveis" (AUTOS, 2012), todavia, se não mediados, podem seguir o curso proposto por Leymann (1996b). Salin (2003b) explica a esse respeito que o agressor, percebendo um risco menor de ser "pego" na organização, pode identificar um campo fértil para as agressões.

Como se observa, por se tratar das relações humanas, o tema em questão é complexo, e muitas táticas do agressor são sutis. Além disso, observa-se que já há álibis erigidos em defesa da violência (GAY, 1995), e o discurso e as práticas das organizações parecem querer transmitir uma imagem de uma violência "normal", e, por vezes, benéfica, ou seja, reina de forma naturalizada a ideologia conformista de que nada pode ser feito. Todos esses indicadores à não caracterização, aquilo que compromete o deferimento da petição, ou seja, todas as barreiras interpostas à vítima, contribuem para que o AM não seja punido.

As táticas identificadas nos 49 casos procedentes foram detalhadas em 22 possibilidades que, em geral, são ministradas pelo agressor em associação, conforme também expressa Adams (1992), como, por exemplo, a cobrança excessiva para o alcance de metas que, geralmente, atrela-se a ofensas verbais, ameaça de demissão, humilhações em reuniões, e ridicularizações. As consequências para as vítimas expostas nos documentos são nefastas; no entanto, não abarcam de maneira mais diretiva consequências sociais ou mesmo organizacionais, não refletindo também a respeito das causas, apenas com citações superficiais a respeito das pressões e demandas da vida moderna. Vale notar que as indenizações, em 35 ocorrências, foram fixadas na faixa de $\mathrm{R} \$ 1.500,00$ até $\mathrm{R} \$ 10.000,00$, contudo; as mudanças de valores ordenados nas diferentes instâncias chegam a causar espanto, sendo a maior redução de $\mathrm{R} \$ 170.000,00$.

As organizações do setor privado responsabilizadas como primeira rés foram agrupadas por segmento, sendo os de maior expressão, respectivamente: o industrial; o varejo; os serviços; os bancos; e o de telecomunicação. Houve, no total, 46 casos de responsabilizações em empresas privadas; 35, de grande porte e 11, de pequeno porte. O número de mulheres que foram assediadas no trabalho nessas empresas foi ligeiramente maior, representando 26 casos, sendo 20, em empresas de grande porte, porém dois desses não se encontravam nas Varas do Trabalho pesquisadas, pois estavam com carga (para cálculos de execução e outro processo foi enviado ao Tribunal Superior do Trabalho), por esse motivo, somente 18 processos estavam disponíveis, pois foram finalizados. 
Dentre os elementos analisados nos processos procedentes, vale ressaltar que tanto os homens quanto as mulheres, em sua maioria, sofreram agressões por parte de um homem. Em apenas oito registros, constatouse a agressão de uma mulher para outra, e quatro registros evidenciaram a agressão de uma mulher para um homem. Essa questão alia-se à supremacia masculina em cargos hierárquicos superiores ao das vítimas. O assédio na direção descendente também foi o mais evidenciado, representando 45 casos, indo ao encontro dos resultados de outras pesquisas (LEYMANN, 1996a; PIÑUEL y ZABALA; CANTERO, 2002; BRADASCHIA, 2007).

Em síntese, o panorama regional oriundo da análise de arquivos referentes a casos de AM tramitados na Justiça do Trabalho (jurisdição em Uberlândia), entre os anos de 2007 a 2011, indica que a agressão é formada por um conjunto de táticas. Essas se sobrepõem e encontram-se dentre outras ações, como deixar o funcionário sem tarefa, agredir verbalmente, isolar a vítima, denegrir sua imagem de maneira sutil, e desqualificar a vítima. Contudo, notou-se que, nos documentos analisados, não há menções objetivas a respeito dos antecedentes do AM, como, por exemplo, questões culturais. Observaram-se apenas citações mais amplas atreladas às pressões constantes no ambiente de trabalho.

Já as consequências do assédio moral nos documentos analisados focam no dano à vítima, mesmo porque, no âmbito legal, é preciso comprovar o ato ilícito, o dano e o nexo causal. Por essa razão, as menções dizem respeito a provas como, por exemplo: atestados médicos, laudos médicos e laudos psicológicos (AUTOS, 2012). Se não ficar notória a extensão dessas consequências, apenas de maneira singela as vítimas exporão em seus depoimentos elementos que indicam que os abalos emocionais prejudicaram o relacionamento com amigos e familiares (AUTOS, 2012). As testemunhas também contribuem, na maioria das vezes (em 42 casos dentre os 49), para a comprovação do assédio; nesse sentido, nota-se que o grupo de trabalho também fica abalado.

Os dados mostram que há convergência da violência em empresas privadas de grande porte (35 casos), todavia, o setor de atuação das empresas é diverso, mas com concentração para organizações de grande porte na indústria, no varejo e em instituições bancárias. Além disso, evidenciam-se 37 agressões sofridas por homens e mulheres por parte de superior hierárquico do sexo masculino, sendo a direção descendente a mais recorrente (45 casos no total). As vítimas trabalharam em cargos diversos, entretanto, tanto homens quanto mulheres ocupavam cargos de nível hierárquico inferior e possuíam baixa escolaridade. De maneira geral, em 42 ocorrências, as vítimas estiveram vinculadas à organização por mais de um ano.

Também foram encontradas divergências no valor das indenizações das decisões procedentes, o que nos leva a pensar sobre a necessidade de disposições legais mais específicas contra o AM, visto que, no Brasil, tal espécie de dano moral ainda não é crime. Ademais, isso reforça a necessidade de discussão acerca das subjetividades que guiam as tomadas de decisões, como expressam Davel e Vergara (2001).

O panorama até aqui discutido mostra a quantidade majoritária não esperada de casos improcedentes. Justificativas decorrentes dessa questão foram apresentadas, e uma visualização dos casos procedentes foi elucidada. A próxima seção analisará dez processos selecionados, a partir de óticas distintas, a fim de enriquecer as discussões.

Dez casos em análise sob óticas distintas

\section{Ótica das vítimas e dos processes jurídicos}

Com relação às categorias do $\mathrm{AM}$, as reflexões, nesse ponto, sob a ótica das vítimas e dos autos, são sintetizadas a seguir: 
- Multicausas: foram apontadas, prioritariamente, em referência às deficiências na gestão de pessoas, como, também, em virtude do despreparo do gestor. Outras contribuições, porém, em menor número, mostram as raízes sociais do problema. Desse modo, há um inter-relacionamento histórico entre cultura e discriminação, apresentando, portanto, um pano de fundo mascarado pela violência institucionalizada (GAY, 1995; HIRIGOYEN, 2010) e, por esse motivo, nem todas as entrevistadas citaram tais questões de natureza subjetiva, relacionada a aspectos culturais. Em um total de 10, as que mais demonstraram discernimento nesse sentido foram três entrevistadas. Cabe ressaltar que o AM sofrido por uma das vítimas foi oriundo do assédio sexual também vivenciado. Outra espécie do gênero dano moral (atos discriminatórios) tolerado por uma segunda vítima (preconceito racial) foi o ponto de partida para o AM. Detalhando um caso, uma das entrevistadas menciona o machismo em sua área de atuação: "[...] quando eu entrei como líder [...] muitos não aceitavam ser liderados por mulher, e ele (o agressor) incentivava esse embate, ele dizia: "mulher não serve pra trabalhar comigo, mulher não serve pra... mulher tem que tá em casa"...Sabe?" (TERCEIRA VÍTIMA).

- Consequências: ficaram notórias as marcas (psicológicas e físicas) deixadas pelo AM na trajetória das vítimas. Em um dos casos, houve um complô de assédio representado por direções mistas, ou seja, na direção horizontal. Seu colega de trabalho, inconformado por vê-la no mesmo cargo que ele, instigou o superior ao qual prestava contas, sob artimanhas machistas, a também perseguir a funcionária (assédio descendente). Nota-se a perda em potencial de profissionais (em sete casos) envolvidas com o trabalho (BERTHELSEN, SKOGSTAD, LAU et al., 2011). Cabe observar que, em quatro situações, as entrevistadas choraram moderadamente durante a entrevista, e uma delas chorou copiosamente. Alguns dos dizeres foram: "[...] eu estudei e foi pra crescer, foi pra melhorar. É humilhante, sabe? Você se sente assim, no fundo do poço, porque eu cheguei aí....no fundo do poço, psicologicamente, eu cheguei a apontar uma arma no espelho uma vez, sabe? [...]" (TERCEIRA VÍTIMA); e "[...] quando você tá lá nessa situação, até você tem dúvidas se você é ou não competente, porque você acaba acreditando que não é” (QUARTA VÍTIMA).

Para as vítimas, a busca pela visibilidade da violência sofrida na justiça, ou seja, mostrar que o ocorrido foi real, representou um desabafo para a maioria delas (em um dos discursos, a entrevistada expressou aos prantos: "gente, eu vivi [...] aconteceu aquilo, então, então eu não tô louca, entendeu?" (QUARTA VÍTIMA), tendo em vista que não foram ouvidas para possíveis mediações nas organizações e tiveram problemas em efeito cascata, como, por exemplo, psicológica, fisicamente, com a família (esposo, filhos (as)), com dívidas (em um dos casos), com dificuldade de voltar a trabalhar em outra empresa devido ao trauma (em oito casos tal problemática foi explicitada diretamente), enfim, elas foram marcadas em sua dignidade. Uma das entrevistadas elucida essa questão: “[...] essa reação vem em cadeia, ela vem em cascata, né, ela vem desencadeando, você sofre... Sofre é... O assédio lá, os maus tratos lá na sua empresa, onde você trabalha [...], você traz aquilo pra casa, mesmo que você não fale do que se trata [...]" (TERCEIRA VÍTIMA).

- Perfil da Vítima: houve citações no seguinte sentido - pessoas que divergem do grupo ou são diferentes em algum aspecto e indivíduos que, por terem maior experiência ou maior escolaridade, suscitam inveja por parte do agressor, o que vai ao encontro dos dizeres de Piñuel y Zabala e Cantero (2002).

- Direções: nas dez entrevistas realizadas com as vítimas, houve assédio descendente; entretanto, em dois casos, houve assédio misto (horizontal e descendente), mas, especialmente, em um deles, o assédio horizontal foi mais expressivo, e nenhum caso de assédio ascendente foi relatado.

- Perfil do Agressor: de modo geral, os agressores são apresentados pelas entrevistadas como pessoas não profissionais e despreparadas para o cargo (por exemplo, falta de estudo específico na área de atuação, no que diz respeito à gestão de pessoas, e falta de preparo para atuação em momentos de crises e desafios). Há ainda considerações mais abrangentes relacionadas à falta de educação dos agressores e indicações de machismo e preconceito por parte de colegas e/ou superior hierárquico. Uma das vítimas que trabalhou na empresa por doze anos e detinha formação na área ilustra essa 
categoria, explicando que uma colega chegou à empresa e algum tempo depois foi promovida a encarregada do escritório. A partir de então, "[...] ela foi eliminando as pessoas que, para ela, eram uma pedra no sapato, né, e eu era uma delas [...]” (PRIMEIRA VÍTIMA).

- Processo (duração, fases, táticas e reação da vítima): o caso de menor duração foi de quatro meses de AM. Nesse caso, dentre as vítimas, houve a discriminação racial como precedente para o AM, e a ex-funcionária tinha contrato temporário. Nos demais casos, apesar da dificuldade das vítimas em apontarem uma data exata para o início do assédio, houve variações - duas vítimas indicaram aproximadamente um ano; outra já sofreu por cerca de dois anos e meio; uma quinta relatou ter vivenciado o processo por um ano e meio, aproximadamente; a sexta entrevistada, por 10 meses; a sétima, por um período em torno de quatro anos; a oitava indicou ter sido alvo por, aproximadamente, um ano e quatro meses; as duas últimas relataram terem experimentado um ambiente hostil no trabalho por seis meses.

Interessante notar que quatro delas destacaram um marco temporal, no qual determinado acontecimento fez com que o assédio aumentasse de modo significativo, como, por exemplo, uma situação em que a gerente tentou obrigar a vítima a realizar uma tarefa que não era de sua alçada, para prejudicá-la e, a partir da negação da funcionária, a perseguição acirrou-se.

Já em relação às fases do AM, apenas uma delas acessou a justiça, estando, na época, trabalhando na empresa, mas foi demitida após revelar tal ação. Outra foi demitida em virtude da crise financeira enfrentada pela filial em que trabalhava aliada ao fato de ela já ter indicado, também, desejo em acessar a justiça. De maneira diferente, três delas, em virtude do ambiente de trabalho tóxico insustentável, pediram demissão. Em outro exemplo, de modo mais específico, a vítima saiu da empresa após a finalização de seu contrato temporário e, por fim, nos quatro últimos casos, elas foram perseguidas e demitidas injustamente com alegações que mascaram o AM. Desse modo, excetuando-se uma das situações relatadas, devido ao contrato temporário, todas as vítimas foram pressionadas e excluídas do mercado de trabalho em função da não mediação do assédio, e, por esse motivo, os processos seguiram o curso apresentado por Leymann (1996b).

A respeito dos atos negativos sofridos pelas vítimas, esses se expressam pela composição de duas tipologias de táticas: mais sutis e menos sutis, sendo a identificação daquelas mais sutis de maior dificuldade, como, por exemplo, boicotar o trabalho da vítima e espalhar rumores negativos sobre o seu trabalho a fim de desmoralizá-la. De fato, há táticas mais associadas a determinadas direções, ademais, as mais sutis são mais difíceis de decifrar, diferentemente, por exemplo, do que uma ameaça aos gritos com utilização de palavras chulas (FREITAS, 2001; CORRÊA e CARRIERI, 2006; BRADASCHIA, 2007; HIRIGOYEN, 2010). Nesse ponto, vale retomar as reflexões contidas nas análises dos autos, os quais sempre reforçam que, na maioria das vezes, há combinações de atos negativos que, em conjunto, passam a expressar condutas agressivas (AUTOS, 2012).

Nos autos, também fica claro o parecer dos juízes em relação à não banalização do AM, uma vez que a punição da organização responsabilizada não pode ser negada mediante a comprovação da violência. Os pareceristas das diversas instâncias se mostram surpresos, principalmente, quanto ao linguajar antiprofissional utilizado por muitos agressores no trato com a vítima, como, por exemplo: chamar a vítima de baleia, fazendo paródias de músicas; usar expressões para constranger e perseguir como: "gaguinho boiola" e "gaguinho viado"; e utilizar palavras como "anta, burro, asno", "seus bostas, seus merdas, seus pamonhas, o uniforme de vocês não serve nem para limpar bunda" (AUTOS, 2012).

Finalizando o conteúdo da categoria AM como processo, tem-se a temática referente à reação das vítimas. Nenhuma das vítimas entrevistadas enxergou espaços confiáveis para denúncia. Quando encontraram brecha para denúncia, não perceberam tratamento adequado, ou investigação, como ocorreu no estudo de Xavier, Barcelos, Lopes et al. (2008). Um caso pode exemplificar - na verdade, houve explícita conivência da diretoria com o comportamento do agressor. Apenas ela (vítima), depois de um período de silêncio e medo, passou a reagir de maneira mais assertiva, buscando reafirmar seus direitos nos diálogos com o agressor. 
Vale ainda destacar o sentimento das vítimas por terem que suportar o assédio. Em um dos casos, tal ideia atrela-se à necessidade de comprovar suas competências, sendo este um desgaste citado por Mattos (2009) referente ao sofrimento da mulher no ambiente trabalho e, por isso, segundo a entrevistada, sua reação significava endurecer. A assediada guardava para si a dor e as injustiças sofridas, as quais refletiram, inclusive, em problemas físicos extremos, como perda de peso excessiva e problemas na coluna. Nesse caso, a vítima trabalhou como vigilante, um cargo tipicamente entendido como masculino. Nos outros casos, as vítimas relataram que, por necessidade financeira, silenciavam sobre a dor sofrida.

\section{Ótica dos (as) gerentes: entrevistas concedidas}

Após as entrevistas com as vítimas, a voz foi dada aos gerentes, como segue:

- Multicausas: os gerentes nessa categoria enfocam diferentes perspectivas. Enquanto um deles menciona “... ser um negócio meio generalizado", dois outros já pontuam a questão afirmando que a causa diz respeito à qualificação deficiente da chefia. Um deles, de maneira mais detalhada, relaciona o assédio ao líder omisso, como é também apontado por Ayoko e Callan (2010), bem como a falta de treinamento na condução de equipe e, de modo mais geral, a educação "no sentido mais amplo da palavra".

De modo antagônico, outro entrevistado associa o assédio ao oportunismo da vítima que, segundo ele, encontra na situação uma oportunidade de obter vantagem financeira, como expresso no trecho: "[...] isso [processos indenizados por dano moral decorrente de assédio moral] até encarece muito o custo para o trabalhador eu acho, eu não sou dono de empresa, eu sou assalariado, empregado, mas tenho essa visão muito clara de como é para o empregador difícil hoje por essa situação, porque eu sei que existe picaretagem, eu sei que existe gente que faz coisa errada, a gente vive no Brasil” (GERENTE B).

Em outro momento, o gerente acima mencionado culpa a potencial vítima de ter uma percepção equivocada sobre as ações do gerente. Também informa que, para evitar problemas no relacionamento interpessoal, é necessário evitar a heterogeneidade no grupo.

De maneira similar, outro gerente procura negar o problema, alegando que o tema é controverso. Este chega a levantar a hipótese de ocorrência do AM em função da comunicação distorcida (culpando também a vítima, pois, de acordo com o gerente, nem todo ato que se julga agressivo, o é de fato), como também do acirramento da competição em um mercado turbulento. Por fim, outro entrevistado, por sua vez, atrela o assédio a questões ligadas a diferenças culturais, exemplificando tais diferenças no cenário brasileiro entre regiões.

- Consequências: os gerentes, por tentarem diminuir, ou mesmo, em dois casos, negar o problema, não explicam com clareza as consequências do AM. Apenas três citações pontuais foram colocadas, como: menor identidade por parte dos funcionários em relação a empresas que não têm imbricado na cultura organizacional a valorização de pessoas; prejuízo na carreira do agressor que, às vezes, por uma "bobeira", comportou-se de modo indevido; e redução da autoridade do chefe que não intervém, por exemplo, no caso do assédio na direção horizontal.

Vale ressaltar a manifestação de um gerente, ao afirmar que, devido ao oportunismo do empregado, a problemática é onerosa para o empregador. Cabe ainda mencionar que, em todo momento, esse entrevistado alegou inocência em relação ao caso de assédio no qual foi citado como agressor e julgado como procedente pela Justiça do Trabalho.

- Perfil da Vítima: das seis entrevistas realizadas, em quatro delas, os gerentes rotularam o perfil da vítima. Além disso, também ocorreram manifestações preconceituosas quando afirmam que: a vítima 
tem pré-disposição em relação à empresa; não possui ensino superior e por isso é mais facilmente manipulável; é psicologicamente instável; não é engajada com o trabalho na empresa; e o funcionário está na profissão errada.

$\mathrm{Na}$ verdade, as alegações dos entrevistados são equivocadas, pois, conforme as proposições de Bradaschia (2007), se a vítima não fosse forte, dificilmente suportaria o prolongar do assédio.

- Direções: vale indicar que não houve consenso nessa categoria. Foi apontado por um dos entrevistados, de modo contrário à literatura (HIRIGOYEN, 2010; BRADASCHIA, 2007, PIÑEL y ZABALA e CANTERO, 2002), que o assédio descendente ocorre em menor incidência; já o horizontal, para ele, é predominante, e, em direção similar, outra gerente apresenta tal afirmação. Já outros dois confirmam que o descendente deve ser o mais recorrente, mas eles justificam de maneira diferente e erroneamente tal alegação. Outro, por sua vez, alega que existe proporção igual entre a direção descendente e ascendente; a de maior ocorrência potencial se dá no sentido horizontal. Por fim, um deles defende maior incidência para a direção descendente e horizontal.

Além das diferentes opiniões, em virtude da própria compreensão limitada do tema pelos entrevistados, alguns gerentes ainda apresentaram justificativas para tais apontamentos, equivocadas. Eles mencionam que o assédio na direção descendente ocorre menos em função do maior conhecimento que o superior de nível hierárquico possui, e, por esse motivo, não deixaria o assédio desenvolver. Um deles insiste em tal questão, informando ser uma tendência a redução do assédio nas empresas, em virtude de os funcionários estarem cada vez mais informados em relação aos seus direitos e em decorrência da maior preparação dos gestores, uma vez que o cenário competitivo pressionaria a isso, não correspondendo essas informações às exposições feitas por Salin (2003b) e Lewis (2006). Outro apregoa o contrário, informando que a direção mais recorrente, a descendente, fundamenta-se na falta de percepção do subordinado em entender que muitas ações não são agressivas, mas, sim, legítimas. Tais percepções também foram encontradas no trabalho de Jenkins, Zapf, Winefield et al. (2011).

Um exemplo é obtido pela colocação de um dos entrevistados que denota sua miopia em relação ao assunto, ao negá-lo: "a grande corporação tem total controle hierárquico sobre todas as esferas, então desde o diretor lá até o carinha que limpa [...]" (GERENTE B). Nesse ponto, cabe destacar que a empresa, após o ocorrido, não demitiu o agressor, como nos outros casos; no entanto, cabe a reflexão de que, simplesmente, chamar o agressor de "maçã podre" (DUFFY, 2009) não resolve o problema, já que a empresa de grande porte deste caso, da área de telecomunicações, é, potencialmente, não apenas coparticipante do problema, mas, também, estimuladora. Isso, porque ela deixa a filial refém de um gerente geral que apresenta tais conteúdos em sua fala; assim, as filiais mais parecem ilhas.

Interessante notar que a vítima do exemplo acima mencionado reflete: "[...] às vezes, começa a aparecer as feridas dentro da empresa que, muitas vezes, levam até a uma... uma falência futura, e começa de um ponto isolado [...]" (SEGUNDA VÍTIMA). A entrevistada ainda afirma que, caso não haja verificação, a problemática tende a se agravar.

- Perfil do Agressor: os gerentes entrevistados nessa categoria novamente não apresentaram consenso. Enquanto houve menções no sentido de o indivíduo no comando possuir uma qualificação deficiente e/ou deixou de receber orientações da empresa, houve também tentativas de reavaliação do termo "agressor". Isso justificado em função de o comportamento agressivo poder, na ocasião, ter sido um "lapso" ou ainda poder ter sido interpretado incorretamente. Percebe-se que esses argumentos expressam a representação de álibis para negar a existência de agressões (GAY, 1995). As ações praticadas, nesse sentido, seriam normais (HELOANI, 2004; FREITAS, 2007a).

Uma entrevistada cita com ênfase que há desvio de caráter do agressor, como se observa no trecho: “[...] um desvio de caráter. Por isso não tende a desaparecer, muitas vezes, a chefia que pratica o assédio moral não se dá conta do dano que causa aos seus subordinados, e acredita que é o modo certo de agir, por isso a duração 
é contínua e não tem fases" (GERENTE E). Outro gerente, corroborando essa versão, comenta que o agressor comete atos negativos por se "achar o dono da verdade", ou porque muitas vezes "o poder sobe à cabeça” (CORRÊA e CARRIERI, 2007). Já um dos entrevistados é menos incisivo e também generalista, pois alega que o fato de o indivíduo ser um agressor pode estar associado ao grau de instrução baixo e, até mesmo, à própria educação familiar.

- Processo (incidência, duração, fases, táticas e reação da vítima): à luz da teoria (LEYMANN, 1996b; BRADASCHIA, 2007), percebe-se o assédio como um processo, e não um fenômeno pontual. Contudo, nem todos os agressores mostraram ter esse conhecimento, alegando, equivocadamente, que o assédio pode ser um fenômeno relâmpago, e o conflito precisa ser resolvido. Por isso, a tendência, na hipótese da falta de acordo, é que uma das partes deixe a organização.

Cabe exemplificar a negação sobre a incidência do AM por um dos gerentes de uma instituição financeira, que explica que o ambiente de trabalho é amistoso e de acesso fácil a todos os níveis da organização, existindo até mesmo a ferramenta "fale com o presidente". Porém, o setor bancário é um dos mais afligidos pelo assédio (BATTISTELLI, AMAZARRAY e KOLLER, 2011). Ademais, uma simples ouvidoria ou código de ética não significa investigação analítica dos casos, nem política profilática eficiente (AUTOS, 2012). Os atos negativos, entretanto, especialmente, na ótica de dois deles, representam em muitas situações normalidade de conduta. Já outro gerente é claro ao dizer que o assédio não se relaciona com potenciais conflitos naturais, mas, sim, com aqueles que avançam os limites do respeito. Uma entrevistada detalha as táticas, explicando que chefes despreparados tendem a se impor com gritos e ameaças. Vale notar que, diretivamente, sobre as fases da violência, não houve apontamentos. Isso pode estar relacionado à própria interpretação reducionista do tema pelos gerentes.

A fim de mediar o problema do assédio e zelar por um ambiente de trabalho saudável, um dos gerentes explica como procede, conforme o trecho a seguir. No entanto, para se referir a uma funcionária, o gerente usa um termo abstrato, vazio e sem identidade, ainda mais desmerecido quando utilizado no seu diminutivo.

A gente procura agir muito pontualmente, caso a caso e, às vezes, um consultor reclama:
"ah, pegou minha venda", né? Chamar e entender a situação e já é... Minar qualquer
possível mágoa que vá ficar daquele evento ali pra poder, como eu te disse, focar adiante
sempre focando no resultado. A gente procura ter muito feedback, tanto um feedback mais
formal de é... "fulaninha, vamos sentar aqui e vamos trocar uma ideia: o que tá
acontecendo, quais são os seus pontos, o que, que você entende?". E, por outro lado, "olha
o que que a empresa espera de você é isso, o que a gente almeja que você busque é isso,
isso, isso" dando um norte pra pessoa (GERENTE B, grifo nosso).

Em um dos momentos da entrevista com o gerente referido, citado como agressor no processo jurídico selecionado, a surpresa se mistura com indignação, ao vê-lo dizer, em tom de ironia, lançando mão de um humor negro, que objetiva diminuir a gravidade de seu discurso e de seu pensamento, que deveria ter cursado veterinária, e não administração. Afinal, lidar com pessoas é, de fato, complexo, deixando subentendido pelo citado gerente que lidar com animais é mais fácil. Tal depoimento é de pasmar. Não seria, então, por esse motivo que, na visão do gerente, em prol de resultados a todo custo, os trabalhadores seriam operários sob o seu reinado?

Desse modo, nas práticas organizacionais, encontram-se, muitas vezes, desvios das atribuições da área de gestão de pessoas, e a violência no ambiente de trabalho acaba banalizada (FREITAS, 2001; HELOANI, 2004; HIRIGOYEN, 2010), criando-se, então, trabalhadores em série, de valores deturpados, representantes de uma dinástica com potencial criminoso.

Finalizando o conteúdo da categoria AM como processo, tem-se a temática referente à reação das vítimas. Conforme um gerente, de maneira irônica, em defesa da própria organização, existe má-fé da vítima ao 
acessar a justiça após a demissão. Isso indica haver um conflito antes não debatido com o gestor, muitas vezes, em razão da assimetria de poder, não apontado de modo explícito por esse entrevistado, ou seja, novamente o gerente (agressor também nesse caso) culpa a vítima. De maneira mais assertiva, nesse tópico, um gerente expõe que a vítima teme reagir em virtude da necessidade do emprego, em muitos casos, e também em função do medo que sente de potenciais represálias, como também apregoa Rodrigues (2009).

\section{Entrevistas não concedidas}

As negativas dos (as) gerentes das empresas citadas nos processos procedentes selecionados parecem divergir das recomendações de uma política diretiva contra o AM no trabalho (SALIN, 2003a; KEASHLY e NEUMAN, 2004; MARTININGO FILHO e SIQUEIRA, 2008), pois indicam falta de transparência. Alguns gerentes negaram, diretamente, o envolvimento na pesquisa, devido às "normas da empresa". Outros, pelo teor do trabalho, expressando na voz receio em falar de tal assunto (DIÁRIO DE CAMPO).

Na Indústria I - líder no mercado brasileiro em sua área de atuação, além de ser uma companhia de capital aberto (SITE EMPRESA I), a vítima alegou que, após sua saída, a empresa passou a desenvolver práticas contra o assédio. Passou a ofertar treinamentos e palestras sobre o assunto, por exemplo. Contudo, a negativa nesta organização, entendida pela extensiva prolongação em não nos atender, causaria no mínimo insegurança por parte de um investidor. O gerente geral, após sucessivas desculpas da secretária (tentando justificar porque ele não retornou para tratar o assunto), repassou para outro profissional a tarefa de responder a pesquisa. Este segundo indicado informou que não poderia nos receber e pediu as questões por $e$-mail, mas nunca respondeu, ou sequer justificou a razão disso. Tudo, portanto, ficou na promessa. Não foi possível, nessa empresa, em nenhum momento, ao menos explicar a pesquisa diretamente para o gerente, porque nenhuma resposta direta nos foi dada, tendo todo o diálogo sido mantido via secretária.

Assim, é de causar estranheza que algumas empresas tenham por norma não discutir o tema, parecendo que a própria organização tem medo de falar do assunto. Isso mostra que sua ação é a própria omissão. As negativas em função de outras demandas e falta de tempo também denotam uma desatenção em relação ao assunto, o que, potencialmente, pode significar uma falha interna da empresa em relação a ele.

Nessas situações, o silêncio e a omissão andam lado a lado. Não discutir as ocorrências na empresa indica que, para esses estabelecimentos, o que houve deve ficar no passado. No entanto se enganam, pois a cada vez que tentam colocar o assunto "por debaixo do tapete", as empresas estão, na verdade, reforçando o comportamento dos assediadores e construindo um significado positivo para tais ações, sob o argumento da dita violência costumeira (MEREU, 2000), que mascara, como uma das vítimas mencionou, as feridas internas na organização.

Salin (2003a) explica que tal conduta cria um terreno fértil à proliferação do assédio que se manifesta como uma epidemia silenciosa (PIÑUEL y ZABALA, 2003) e representa diversos efeitos prejudiciais à organização. Entre esses, estão o alto absenteísmo, aumento na rotatividade, queda na produtividade, baixa satisfação com a empresa, queda no comprometimento organizacional, atos agressivos contra a empresa. Inclusive, pode-se elencar a baixa confiança nos líderes, aumento na frustração, piora no ambiente de trabalho, aumento nos custos de produção, piora da imagem da empresa, perda de clientes, sobrecarga de trabalho sobre colegas, entre outros (BRADASCHIA, 2007).

\section{Considerações Finais}

Sob o foco dos discursos dos gerentes, cabe reafirmar os descompassos em relação às outras óticas, principalmente, a ótica das vítimas, em decorrência das contradições e equívocos relacionados ao AM por parte dos gerentes. Um exemplo é a citação de um dos gerentes que menospreza uma potencial vítima, ao dizer "... filha da putismo existe em todo lugar" (GERENTE B). Na verdade, ele busca isentar o gerente e a 
organização de qualquer responsabilidade em relação ao fato ocorrido no ambiente de trabalho. Os gerentes também se expressam por intermédio de eufemismo e ainda buscam levar os discursos em tom de "brincadeira", representando, portanto, álibis naturalizados em nossa sociedade.

A violência parece costumeira, tendo em vista, principalmente, o medo, representado pelo temor de perder o seu posto, e o abuso do poder, ou seja, de querer reinar, pisando nas outras pessoas. Tal problemática parece ainda agravar-se quando esse outro pertence a minorias, como, por exemplo: mulheres, negros(as), homossexuais, e, ainda, aquelas(es) que não se encaixam nos limites impostos esteticamente, especialmente, pela mídia.

Os rótulos e preconceitos apresentados pelos gerentes em relação ao perfil da vítima aludem a uma escusa da organização sobre o papel que lhe cabe, no sentido de zelar por um ambiente de trabalho saudável. Há insistência em não retirar a venda dos olhos a respeito do tema e, por esse motivo, falta percepção de que a epidemia do AM no trabalho prejudica potencialmente a própria saúde financeira da organização, pois fragiliza as pessoas que trabalham pelo resultado da organização. Isso foi mostrado a partir de elucidações sobre a identidade que as vítimas tinham para com a empresa, especialmente, nos cinco casos, em que menções nesse sentido foram explícitas.

As mulheres pesquisadas mostram que o assédio ocorre em diferentes faixas etárias, bem como em mulheres de distintos graus de instrução. Todavia, tende a marcar de maneira mais extensa aquelas que se dedicaram a uma empresa por diversos anos (notadamente em cinco casos dos dez pesquisados), construindo suas carreiras nesses ambientes e, de maneira prolongada, passam a ser agredidas em sua dignidade. Essas pessoas são, pode-se dizer, usurpadas por agressores ou agressoras (em dois casos) da possibilidade de crescer na organização, sendo então demitidas por álibis que despertam nas vítimas inconformismo e revolta.

Observa-se, portanto, que o assédio dilacera oportunidades, deixando o trabalhador sob a mira do medo, e, além disso, visto e compreendido de forma parcial e não como um ser integral. A violência ainda compromete as potenciais vantagens competitivas das organizações em virtude do ambiente tóxico vivenciado pelas pessoas. Nesse contexto, as expectativas em relação ao trabalho são frustradas e os malefícios dessa doença social retroalimentam-se e agravam-se a partir da não mediação. Em decorrência da complexidade do processo do AM, como também os impactos negativos que provoca, a escolha pela mediação preventiva é a mais prudente, uma vez que essa atua sobre os atos agressivos mais explícitos e os menos visíveis, estimulando o não concordar coletivo, posto que "ignorância não é álibi" (FREITAS, 2007b, p. 284).

Uma das principais contribuições desse estudo ocorre ao tentar apresentar três óticas do assédio: da vítima, do gerente da empresa responsabilizada e da justiça. Entende-se que a junção desses três discursos oferece uma visão mais ampla do processo, ao mesmo tempo que indica as especificidades. A amplitude reforça a necessidade de eliminar esse mal de nossa sociedade; já as especificidades apontam para: a necessidade de melhorar a estrutura do judiciário, dando mais agilidade às sentenças; a urgência de capacitar os gerentes para que os mesmos possam ver os efeitos nefastos do assédio; e a criação de um serviço para o acompanhamento ao desgaste mental das vítimas de assédio.

Dadas as considerações apresentadas, tem-se a consciência de suas limitações, tais como: seleção dos processos na primeira fase do estudo, que pode não ter sido plena, e a veracidade das informações, considerando a ótica tanto das vítimas quanto dos gerentes. No caso das vítimas, ainda há a questão da memória seletiva, pois houve, por exemplo, processos finalizados em 2007 e outros, em 2011.

Com vistas à expansão da discussão sobre a complexidade das relações que ocorrem no espaço entre o Eu e o Outro, bem como os impactos dessas relações, a partir da violência moral no trabalho, propõem-se estudos longitudinais de base interpretativa. Também seria interessante mapear, pelo menos, as ocorrências formais de AM no trabalho no Brasil, de acordo com as regiões, no intuito de ampliar as discussões, tomando como base as óticas distintas, como as apresentadas neste estudo. 


\section{Referências}

ADAMS, A.; BRAY, F. Holding out against workplace harassment and bullying. Personnel Management, v. 24, n. 10, p. 48-52, 1992.

AGERVOLD, M. Bullying at work: a discussion of definitions and prevalence, based on an empirical study. Scandinavian Journal of Psychology, v. 48, n. 2, p. 161-172, 2007.

ANDRADE, M. M. de. Como Preparar Trabalhos para Cursos de Pós-Graduação. São Paulo: Atlas, 2004.

AYOKO, O. B.; CALLAN, V. J. Teams' reaction to conflict and teams'task and social outcomes: the moderating role of transformational and emotional leadership. European Management Journal, v. 28, n. 3, p. 220-235, 2010.

BAILLIEN, E. et al. A qualitative study on the development of workplace bullying: towards a three way model. Journal of Community \& Applied Social Psychology, v. 19, n. 1, p. 1-16, 2009.

BARRETO, M. Violência, saúde e trabalho: uma jornada de humilhações. São Paulo: EDUC, 2006.

BATTISTELLI, B. M.; AMAZARRAY, M. R.; KOLLER, S. H. O assédio moral no trabalho na visão de operadores do direito. Psicologia e Sociedade, v. 23, n. 1, p. 35-45, 2011.

BAUER, M. W. Análise de conteúdo clássica: uma revisão. In: BAUER, M. W.; GASKELL, G. Pesquisa Qualitativa com Texto, Imagem e Som: um manual prático. 7. ed. Petrópolis: Vozes, 2008, 189-217 p.

BERTHELSEN, $M$ et al. Do they stay of do they go? A longitudinal study of intentions to leave and exclusion from working life among largets of workplace bullying. International Journal of Manpower, v. 32, n. 2, p. 178-193, 2011.

BORSOI, I. C. F.; RIGOTTO, R. M.; MACIEL, R. H. Da excelência ao lixo: humilhação, assédio moral e sofrimento de trabalhadores em fábricas de calçados no Ceará. Cadernos de Psicologia Social do Trabalho, v. 12, n. 2, p. 173187, 2009.

BRADASCHIA, C. A. Assédio moral no trabalho: a sistematização dos estudos sobre um campo em construção. 2007. 230f. Dissertação (Mestrado em Administração de Empresas). Fundação Getulio Vargas, São Paulo, 2007.

CORRÊA, A. M. H.; CARRIERI, A. de P. Percurso semântico do assédio moral na trajetória profissional de mulheres gerentes. Revista de Administração de Empresas, São Paulo, v. 47, n. 1, p.22-32, 2007.

DANIEL, T. A. "Tough boss" or workplace bully?: a grounded theory study of insights from human resource professionals. 2009. 260f. Tese (Doutorado em Filosofia) Fielding Graduate University, Santa Barbara - CA/USA, 2009.

DAVEL, E.; VERGARA, S. C. Gestão com Pessoas, Subjetividade e Objetividade nas Organizações. In: DAVEL, E.; VERGARA, S. (Org.). Gestão com Pessoas e Subjetividade. São Paulo: Atlas, 2001, 29-56 p.

DUFFY, M. Preventing workplace mobbing and bullying with effective organizational consultation policies, and legislation. Consulting Pychologist Journal: Practice and Research, v. 61, n. 3, p. 242-262, 2009.

EINARSEN, S. The nature and causes of bullying at work. International Journal of Manpower, v. 20, n. 1/2, p. 1627, 1999.

EINARSEN, S. Harassment and bullying at work: a review of the scandinavian approach. Aggression and Violent Behavior, v. 5, n. 4, p. 379-401, 2000.

ENRIQUEZ, E. O homem do século XXI: sujeito autônomo ou indivíduo descartável. RAE - Eletrônica, v. 37, n. 2, p. 6-17, abr/jun, 1997. Disponível em: < http://rae.fgv.br/sites/rae.fgv.br/files/artigos/10.1590_S167656482006000100011.pdf>. Acesso em: 18 mar. 2012. 
FARIA, J. H. Poder real e poder simbólico: o mundo das intrigas e tramas nas organizações. In: CARRIERI, A. de P.; SARAIVA, L. A. S. Simbolismo Organizacional no Brasil. São Paulo: Atlas, 2007, 61-86 p.

FREITAS, M. E. de. Assédio Moral e Assédio Sexual: faces do poder perverso nas organizações. Revista de Administração de Empresas, São Paulo, v. 41, n. 2, p. 8-19, abr./jun. 2001.

FREITAS, M. E. de. Quem paga a conta do assédio moral no trabalho. RAE eletrônica, São Paulo, v. 6, n. 1, Art. 5, jan./jun. 2007a. Disponível em: < http://rae.fgv.br/sites/rae.fgv.br/files/artigos/10.1590_S167656482007000100006.pdf>. Acesso em: 18 mar. 2012.

FREITAS, M. E. de. A metáfora da guerra e a violência no mundo do trabalho. In: CARRIERI, A. de P.; SARAIVA, L. A. S. Simbolismo Organizacional no Brasil. São Paulo: Atlas, 2007b. 277-291 p.

FREITAS, M. E. de; HElOANI, R.; BARRETO, M. Assédio Moral no Trabalho. São Paulo: Cengage Learning, 2008.

GAY, P. O Cultivo do ódio. V. III. Companhia das Letras. São Paulo: Editora Schwarcz, 1995.

GILL, R. Análise de discurso. In: BAUER, M. W.; GASKELL, G. Pesquisa Qualitativa com Texto, Imagem e Som: um manual prático. 7. ed. Petrópolis: Vozes, 2008, 244-270 p.

HELOANI, R. Assédio Moral: um ensaio sobre a expropriação da dignidade no trabalho. RAE eletrônica, São Paulo, v. 3, n. 1, Art.10, jan./jun. 2004. Disponível em: 〈http://www.scielo.br/pdf/raeel/v3n1/v3n1a12.pdf >. Acessado em: 10 mar. 2012.

HELOANI, R. Gestão e organização no capitalismo globalizado: história da manipulação psicológica no mundo do trabalho. São Paulo: Atlas, 2010.

HIRIGOYEN, M. F. Mal-Estar no Trabalho: redefinindo o assédio moral. 5. ed. Rio de Janeiro: Bertrand Brasil, 2010 .

HÉRITIER, F. Definições. In: BARRET-DUCROCQ, F. A. A Intolerância. Rio de Janeiro: Bertrand Brasil, $2000,24-$ $27 \mathrm{p}$.

JENKINS, M. F. et al. Bullying allegations from the accused bull's perspective. British Journal of Management, v. 10, p. 1-13, 2011. Disponível em: < http://www.aboto.com.au/cmsfiles/documents/BJM-Article.pdf>. Acesso em: 05 fev. 2012.

JOVCHELOVITCH, S.; BAUER, M. W. Entrevista narrativa. In: BAUER, M. W.; GASKELL, G. Pesquisa Qualitativa com Texto, Imagem e Som: um manual prático. 7. ed. Petrópolis: Vozes, 2008, 90-113 p.

KEASHLEY, L.; NEUMAN, J. H. Bullying in the workplace: Its impact and management. Employee Rights and Employment Policy Journal, v. 8, n. 2, p. 335-373, 2004.

LE GOFF, J. O passado da intolerância. In: BARRET-DUCROCQ, F. A. A Intolerância. Rio de Janeiro: Bertrand Brasil, 2000, 38-41 p.

LEWIS, S. E. Recognition of workplace bullying: a qualitative study of women targets in the public sector. Journal of Community \& Applied Social Psychology, v. 16, n. 2, p. 119-135, 2006.

LEYMANN, H. The content and development of mobbing at work. European Journal of Work and Organizational Psychology, v. 5, n. 2, p. 165-184, 1996a.

LEYMANN, H. La Persécution au Travail. Paris: Éditions du Seuil, 1996b.

MARCONI, M. de A.; LAKATOS, E. M. Metodologia Científica. São Paulo: Atlas: 2006. 
MARTININGO FILHO, A.; SIQUEIRA, M. V. S. Assédio moral e gestão de pessoas: uma análise do assédio moral nas organizações e o papel da área de gestão de pessoas. RAM, v. 9, n. 5, p. 11-34, 2008.

MATTOS, A. H. G. A ocupação feminina no mercado de trabalho: desafios para a gestão contemporânea das organizações. Gestão Contemporânea, Porto Alegre, n. 6, p. 23-43, jan./dez. 2009.

MEREU, I. O passado da intolerância. In: BARRET-DUCROCQ, F. A. A Intolerância. Rio de Janeiro: Bertrand Brasil, 2000, 42-45 p.

PIÑUEL y ZABALA, I. Mobbing, la lenta y silenciosa alternativa al despido. 2003. Disponível em: < www.mobbing-opinion.com >. Acesso em: 04 mar.2012.

PIÑUEL y ZABALA, I.; CANTERO, A. O. Informe Cisneros II. La incidencia del mobbing o acoso psicológico en el trabajo en España. Universidad de Alcalá de Henares, 2002.

RAYNER, C.; SHEEHAN, M.; BARKER, M. Theoretical approaches to the study of bullying at work. International Journal of Manpower, v. 20. n. 1/2, p. 11-15, 1999.

RICCEUR, P. Definições. In: BARRET-DUCROCQ, F. A. A Intolerância. Rio de Janeiro: Bertrand Brasil, 2000. 20$23 \mathrm{p}$.

RODRIGUES, M. Categorias de Assédio Moral no Ambiente Organizacional: uma proposta de análise. In: ENCONTRO NACIONAL DOS CURSOS DE PÓS-GRADUAÇÃO EM ADMINISTRAÇÃO, 33, 2009 , São Paulo. Anais... São Paulo: ANPAD, 2009. 1 CD-ROM.

SALIN, D. Ways of explaining workplace bullying: a review of enabling, motivating and precipitating structures and processes in the environment. Human Relations, v. 56, n. 10, p. 1213-1233, 2003a.

SALIN, D. Workplace bullying among business professionals: prevalence, organizational antecedents and gender differences. 2003. 73f. Thesis (PhD Thesis), Swedisch School of Economics and Business Administration, Helsinki, 2003b.

SIQUEIRA, T. L. Joan Scott e o papel da história na construção das relações de gênero. Revista Artemis, v. 8, p. 110117 , jun. 2008.

TRACY, S.; LUTGEN-SANDVIK, P.; ALBERTS, J. Nightmares, demons and slaves. Exploring the painful metaphors of workplace bullying. Management Communication Quarterly, v. 20, n. 2, p. 148-185, 2006.

XAVIER, A. C. H. et al. Assédio moral no trabalho no setor saúde no Rio de Janeiro: algumas características. Revista Brasileira de Saúde Ocupacional, São Paulo, v. 33, n. 117, p. 15-22, 2008.

YIN, R. K. Estudo de caso: planejamento e métodos. 2. ed. Porto Alegre: Bookman, 2001. 